\title{
Sites of Chemistry in the Nineteenth Century
}

\author{
Antonio Belmar \\ University of Alicante, Spain
}

The three articles in this special issue of Ambix were among the twenty-one papers presented at the conference 'Sites of Chemistry in the Nineteenth Century,' held in Valencia at the Institute for the History of Medicine and Science 'López Piñero' in July 20I2. This meeting was the second of the series of conferences organised as part of the project Sites of Chemistry, 1600-2000, the aim of which was to investigate the wide and diverse range of physical spaces and places where chemistry has been practised from the early modern period to the twentieth century.

Many historians of chemistry have employed printed, manuscript and iconographic sources in order to show what different sites of chemistry looked like in the past, how they were geographically distributed, and how objects and users were placed within them. But it is certainly more difficult to discuss how these sites were shaped, physically, socially and culturally, and how they interacted with the making and communication of chemical knowledge. Sites of chemistry are very often presented as containers, as backdrops, as passive scenarios where chemical activities took place. A primary objective for the Sites of Chemistry project has been to offer a forum where historians of chemistry are encouraged to reflect on the role of sites and places as active components of chemical knowledge production and communication practices.

At the end of the I980s, Owen Hannaway argued that the appearance of the laboratory was indicative of the emergence of a new mode of scientific inquiry. He claimed that the intellectual, cultural and social features of this new way of conceiving the study of matter were encoded in the walls of the new places created to

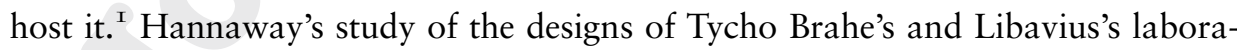
tories and the different conceptions of the science of matter they reflected was a suggestive reflection about the deeply spatial nature of chemistry, a science that, from its origins, has been closely tied to the place in which it is practised. Since then research laboratories have captured the attention of historians of science and, accordingly, the Sites of Chemistry project could not neglect them. However, given the

\footnotetext{
Owen Hannaway, "Laboratory Design and the Aim of Science: Andreas Libavius Versus Tycho Brahe," Isis 77 (I986): 584-6ro.
} 
importance accorded to research laboratories in the historiography of chemistry, it was clear from the beginning that a major challenge for the project would be to move away from the research laboratory and to look for chemistry outside the walls of this privileged space.

Enlarging the notion of 'chemical practice' was the first conceptual shift to be promoted. It has to include teaching and learning; trade, industrial application and routine analysis; theoretical debate and popular dissemination. It was also important to adopt a wider perspective when thinking about 'chemical sites' to include classrooms and lecture theatres; shops and markets; salons and coffee-shops; factories, workshops and mines; pharmacies and hospitals; tax offices or law courts; army quarters and military schools; cities and countryside ... . Inside-outside interactions were another aspect to be considered, trying to locate sites of chemistry within their wider, external environments, in particular through the detailed examination of chemists' interactions with other actors, in and around specific sitesthereby exploring the wider social, economic, political and cultural contexts for the practice of chemistry. In this respect, it was important to encourage investigations dealing with the circulation of people, ideas, practices and material objects around the chemical world and to explore the ways in which chemical practices, ideas, and models of organisation were adapted and transformed as they moved from place to place. And, last but not least, we agreed that one benefit of the Sites of Chemistry project should be the opportunity to examine geographical regions and countries that have been under-represented in recent literature. It was therefore a self-conscious decision to focus on those papers dealing with chemical sites in countries that have been less frequently represented in histories of chemistry, but which provide compelling illustrations of the themes defining the project.

Fortunately, the project was born at an auspicious time for achieving its objectives, since the historiography of science of the last two decades has offered a large variety of concepts, approaches and questions that have proved very helpful in linking science with the sites, places and territories where it was practised. ${ }^{2}$ For example, a number of studies have shown that factors such as the location of laboratories and science buildings in an urban context, their design and internal layout, the division between public and private spaces, and ways of establishing physical or symbolic barriers and gates, constituted key elements in understanding the intellectual and ideological roots that inspired the emergence of new scientific disciplines. ${ }^{3}$

2 Steven Shapin, "Placing the View from Nowhere: Historical and Sociological Problems in the Location of Science," Transactions of the Institute of British Geographers 23 (I998): 5-I2; Charles Withers, "Place and the 'Spatial Turn' in Geography and in History," Journal of the History of Ideas 70 (2009): 637-57; David A. Finnegan, "The Spatial Turn: Geographical Approaches in the History of Science," Journal of the History of Biology 4I (2008): 369-88; Adi Ophir and Steven Shapin, "The Place of Knowledge. A Methodological Survey," in The Place of Knowledge: The Spatial Setting and its Relation to the Production of Knowledge, ed. Adi Ophir, Steven Shapin, and Simon Schaffer; Science in Context 4 (I 99I): 3-2 I; Crosbie Smith and Jon Agar, eds., Making Space for Science: Territorial Themes in the Shaping of Knowledge (London: Macmillan, I998).

3 Jole Shackelford, "Tycho Brahe, Laboratory Design, and the Aim of Science: Reading Plans in Context," Isis 84 (I993): 2II-30; Thomas F. Gieryn, "Laboratory Design for Post-Fordist Science," Isis 99 (2008): 796-802; R. W. Home, "Building a Laboratory in the Late I9th Century: New Requirements for a New Style of Physics," 
The idea of discipline formation lay at the core of many of these studies and is also an important topic in the historiography of chemistry. Mapping the internal arrangement of laboratories has been, for many authors, a way to illuminate the spatial dimension of disciplinary formation, especially in the nineteenth and twentieth centuries. If we admit that structures are always intended to be used in particular ways, then they offer us information about the science they were designed to house. In so far as structures reflect the self-image and ethos of a discipline, there is much to learn about discipline identity by studying how their settings are social, symbolical and physically constructed.

Historians of sciences coming from, or inspired by, the history of architecture have also pointed out that the architectural style and functional typology of buildings created to host scientific activities give us valuable information about the public 'images' of science that their creators and users wanted to transmit. ${ }^{4}$ From this point of view, paying attention to the physical aspects of the buildings, their visual language and their capability to encode knowledge in material forms, can contribute to a greater understanding of how science is located within the economic, cultural, and intellectual spaces of the age.

For many other authors, the main question has been how trust, legitimacy and credibility is locally gained, why certain places confer or undermine the credibility of scientists and their claims, who is benefitting from these and by whom are they being challenged. ${ }^{5}$ The central role given to the audiences, to the witnesses, is probably one of the major contributions of this series of studies. We can find in this literature very useful analyses of the ways the public and experimenters were arrayed in the locations in which experimental knowledge was produced, evaluated and legitimated; how the conditions of access to these places were established; how transactions across their thresholds were managed; and how physical sites constrain and reflect human actors' behaviour.

More recently, for a growing number of historians the focus on how knowledge is made in specific sites, regions or territories has moved on, towards a new concern

3 Continued

in I beni culturali scientifici nella storia e didattica, ed. Fabio Bevilacqua (Pavia: Univ. degli Studi, I993), 29-37; R. W. Home, "Learning from Buildings: Laboratory Design and the Nature of Physics," in Non-Verbal Communication in Science Prior to 1900, ed. Renato G. Mazzolini (Firenze: Leo S. Olschki, 2003), 587-608.

4 Sophie Forgan, "The Architecture of Science and the Idea of a University," Studies in History and Philosophy of Science 20 (1989): 405-34; Sophie Forgan, "The Architecture of Display: Museums, Universities and Objects in Nineteenth-Century Britain,” History of Science 32 (1994): 139-62; Sophie Forgan, "Building the Museum: Knowledge, Conflict and the Power of Place," Isis 96 (2005): 572-85; Sophie Forgan, "Context, Image and Function: A Preliminary Enquiry into the Architecture of Scientific Societies," BJHS I9 (I986): 89-II3; Thomas A. Markus, Buildings and Power: Freedom and Control in the Origin of Modern Building Types (London: Routledge, I993); Thomas A. Markus and D. Cameron, Words Between the Spaces: Buildings \& Language (London, Routledge, 200I).

5 Steven Shapin, “The House of Experiment in Seventeenth-Century England," Isis 79 (I988): 373-404; Jan Golinski, 2 "The Place of Production" in Making Natural Knowledge: Constructivism and the History of Science (Cambridge: Cambridge University Press, I998), 79-103; Thomas F. Gieryn, “Three Truth-Spots," Journal of the History of the Behavioral Sciences 38 (2002): II3-32; Thomas Gieryn, Cultural Boundaries of Science: Credibility on the Line (Chicago: University of Chicago Press, I999); Thomas F. Gieryn, "City as Truth-Spot: Laboratories and Field-Sites in Urban Studies," Social Studies of Science 36 (2006): 5-38. 
with how transactions occur between places. ${ }^{6}$ This change of perspective from the situated nature of scientific knowledge production and reception to the migratory patterns of science on the move has implied the emergence of new analytical categories as well as new questions and perspectives used to understand how ideas, materials, people and even models of scientific organisation and spaces move between places.

Besides the intellectual agendas underlying this rich and heterogeneous historiography, and despite our agreement or disagreement, interest or disinterest in them, studies dealing in one way or another with the spatiality of scientific knowledge offer us a number of valuable methodological tools, analytical concepts and perspectives for inquiry that historians of chemistry cannot disregard. Encouraging dialogue with this rich literature on the 'geographies of past scientific knowledge' was, from the beginning, a strategic aim of the Sites of Chemistry project. Our reading was necessarily critical, since most of these concepts, methods and approaches were based on and applied in natural history, physics and biomedical studies, chemistry being surprisingly absent. ${ }^{7}$ The large variety of historical and geographical contexts explored in the series of conferences and publications promoted by the project constitutes a good opportunity to test and reflect on the validity and utility of such concepts, methods and perspectives when dealing with the sites, places and territories in which chemistry was produced, communicated and put in transit from the seventeenth century to the twentieth.

Readers of the three papers included in this volume will observe how data, theories, epistemic values, and experimental practices circulated across courtrooms, laboratories, salons, academies, lecture halls, and private spaces in nineteenthcentury Paris in the hands of a chemistry academician, professor and expert, as well as talented singer and lively polemicist; how teaching, research, ceremonial and consultancy activities coexisted and interacted inside the largest pharmaceutical manufacturing laboratory in seventeenth- and eighteenth-century London, and how it declined in the nineteenth century as a consequence of the obsolescence of multifunctional laboratories in a time of increasing specialisation; and how the interplay between personal research interests and teaching conceptions, disciplinary definition and specialisation, technical requirements, academic hierarchies, social organisation of work and cultural and political ambitions of local government, helped to shape the internal distribution and design of an ephemeral model for chemistry laboratories in the mid-nineteenth century.

Concepts such as 'multifunctional,' 'model,' 'conservatism' and 'hybridisation' are used in these three papers to interrogate plans, engravings, letters, reports,

6 David N. Livingstone, Putting Science in its Place: Geographies of Scientific Knowledge (Chicago, IL: University of Chicago Press, 2003); James A. Secord, "Knowledge in Transit," Isis 95 (2004): 654-72; Kostas Gavroglu et al., "Science and Technology in the European Periphery. Historiographical Reflections," History of Science 46 (2008): I 53-75.

7 See for instance David N. Livingstone and Charles Withers, eds., Geographies of Nineteenth-Century Science (Chicago, IL: University of Chicago Press, 20I I). 
newspapers, accounting books and commemorative publications in an attempt to understand how chemistry was produced, communicated and circulated inside and between different sites. They are also deployed to investigate how these sites were designed and transformed in order to host a wide variety of pedagogical, scientific, professional, commercial and political practices in a time of deep institutional, scientific, industrial and pedagogical transformation.

Robert Wilhelm Bunsen's laboratory in Heidelberg is portrayed by Christine Nawa as an 'intermediate stage' between an early-nineteenth-century first generation of German laboratories which were accommodated in pre-existing spaces and the I 860 s purpose-built 'chemistry palaces.' Following a character-centred approach, Nawa offers us a detailed analysis of the architectonical, material and organisational features that made Bunsen's laboratory a model for future chemistry institutes. From this point of view, Nawa's study invites us to learn and to reflect about what a model is made of and how this recognition is attained. Anna Simmons's study of the Apothecaries' Hall laboratories in the context of early-nineteenth-century London is an interesting example of the complex adaptation of a laboratory designed to the standards of eighteenth-century chemistry to the profound transformations of chemistry teaching, research and industry during the nineteenth century. The conservative nature of the Society of Apothecaries, and its resistance to introduce substantial changes in its administrative and business practices, is identified in Simmons's study as a key factor in explaining the difficulties it experienced in adapting the multifunctional structure of Apothecaries' Hall laboratories, inherited from the eighteenth century, to the development of specific research and teaching institutions and the increasing specialisation and growing professionalisation within the chemical community. José Ramón Bertomeu-Sánchez's paper reviews the broad range of multifaceted activities developed by one of the most famous nineteenth-century toxicologists, Mateu Orfila (I787-I853). By following Orfila's biographical pathway, Bertomeu-Sánchez explores four main sites of nineteenth-century French toxicology: classrooms, salons, academies, and courts. He reviews the location and physical shape of each site, the explicit or implicit rules concerning access, and the activities developed by the different inhabitants. He shows how these features largely shaped the authority of Orfila and the development and closure of the controversies in which he was involved. Moreover, by connecting these different sites, Orfila encouraged the exchanges of objects, data, epistemic values, controversies and experimental practices which produced some overlapping and hybridisation. The study confirms that a biographical approach provides a privileged perspective from which to discuss how physical environment constrains scientific practice while enlarging the map to include new, unexplored sites which played an important role in the development of chemistry during the nineteenth century.

\section{Notes on contributor}

Antonio Belmar. Address: Email: Belmar@ua.es 


\section{Authors Queries}

Journal: Ambix

Paper: $\quad$ AMB_61_2_INTRO

Article title: Sites of Chemistry in the Nineteenth Century

Dear Author

During the preparation of your manuscript for publication, the questions listed below have arisen.

Please attend to these matters and return this form with your proof. Many thanks for your assistance

\begin{tabular}{|l|l|l|}
\hline $\begin{array}{l}\text { Query } \\
\text { Reference }\end{array}$ & Query & Remarks \\
\hline 1 & $\begin{array}{l}\text { Please confirm the short affiliation and } \\
\text { provide 'Notes on contributor' for Antonio } \\
\text { Belmar. }\end{array}$ & \\
\hline 2 & $\begin{array}{l}\text { Note 5: Please provide the editor names in } \\
\text { Golinski (1998). }\end{array}$ & \\
\hline
\end{tabular}

